\title{
Financial Control Systems and Financial Systems Theory: Free Cash Flow and Profitability Nexus: A comparative study of Manufacturing Firms in Nigeria and Ghana
}

\author{
EMEKA BENNETT NWUBA, ALEXANDER EHIMARE OMANKHANLEN, \\ PEACE ONYEDIKACHI CHIMEZIE, LAWRENCE UCHENNA OKOYE
}

\author{
Department of Banking and Finance Covenant University, Ota, NIGERIA
}

\begin{abstract}
In Financial Systems, the impact of Free Cash Flow (FCF) on the performance of a company has been in the center of academic discourse in recent years. Several studies have tried to ascertain the nature and magnitude of the relationship between free cash flow and firm profitability with conflicting results coming from different scholars. The main objective of this research work was to examine the impact of FCF on the profitability of quoted manufacturing firms in the Nigerian and Ghana stock exchanges. Data were pooled from twenty (20) different companies (ten each from Nigeria and Ghana)

for a period of six years $(2012$ - 2017). A panel data estimation model was used to measure the impact of FCF and other performance metrics on the Return on Assets (ROA), which is our chosen profitability measure. The results show a positive but insignificant relationship between FCF and ROA both for Ghana and Nigerian manufacturing firms. Also, sales growth showed a positive impact on profitability of both countries while leverage negatively impacted on profitability. with Ghana being significant at 5\%. The implication of the findings of the study is that it makes no business sense for companies to keep piling up excess funds beyond that which is needed for transactional purposes. The similarity between the results from Ghana and Nigeria in most of the variables shows that the findings of this study can be generalized to other countries. Based on the findings of the study, we recommend that the management of companies should strive to keep only the minimum needed free cash flow while the rest should be invested in other projects with positive net present value
\end{abstract}

Keywords: Financial Control Systems, Financial Systems Theory, Free Cash Flow, Return on Assets, Asset Tangibility, Current Ratio and Leverage

Received: June 25, 2020. Revised: November 1, 2020. Accepted: November 17, 2020. Published: December 7, 2020.

\section{Introduction}

Financial Control Systems and Financial Systems Theory has received much attraction in recent decades due to the impact in real economy and due to numerous of applications. Financial Control Systems and Financial Systems Theory has numerous application in Debt Theory Analysis, Stock Exchanges Analysis, Precious Medals analysis, Cryptocurrency analysis, Central Banks' Systems
Theory etc. Systems Theory is combined with Financial Systems nowadays.

Profitability is a key measure of performance in profit-oriented firms. Financial analysts have focused mainly on using profitability as a measure of soundness or otherwise of an organization. This profitability-based focus on performance analysis is anchored on the profit maximization objective of the firm. Profitability however may not be the ultimate determinant of 
the health status of firms. Liquidity (or cash flow) has been attracting so much focus in recent years. This is because a firm might be profitable but may not be generating enough cash flow to meet short-term maturing obligations [23] stated that there is a linear relationship between firms' efficient operations and its liquidity. Thus, it is imperative for management to uphold an optimal liquidity level that enables the organization to pay dividend and invest in profitable projects. In order to ensure optimal liquidity, firms must follow the principles relating to cash management, capital structure and working capital management. The concept of free cash flow, is the net cash earned by a company from operating activities after deductions for fixed costs or replacement of assets. It is the sum of cash available to the company after paying all business operating cost and necessities needed to keep it in operational form [24]. Free cash flow is an indicator of efficiency of firms around the world today. It enhances the ability of the firm to maximize their shareholders' wealth and also an indicator to investors that seek after investment opportunities in the financial market. Free cash flow is a reflection of the availability of cash for the firm after relevant cost of business growth and purchase of asset. Due to the significance of free cash in the operation of a firm, firms try to sway their free cash flow position by extending the payment of payables and reducing the receivable collection time [6]. Free cash flow is the available liquidity of the firm after providing for expansion cost. This liquidity can create agency problem whereby managers prefer investing on assets that generate returns that will maximize their selfish desire at the expense of shareholders. The investment decision of a firm is sensitive to the availability of free cash flow. This is simply because the ability of the firm to invest can be affected by the cash flow position of the business. Thus, management must ensure its effective utilization so as to maximize the shareholders' value [20]. Corporate managers approach the issue of free cash flow based on different views on their relative importance in the performance of their organizations. While some see free cash flow from a purely risk management perspective (staying liquid to avoid operational hitches), others handle free cash flow from both risk management and profitability perspective. Such managers believe that the more a company keeps stock of free cash, the greater the chances of being able to invest in future projects that will be more profitable than those available now. This free cash flow and profitability nexus is what drives corporate managers toward seeking more and more free cash in their balance sheet. However, the extent to which a company's free cash flow can positively impact on its profitability remains unclear/ This study examined the impact of free cash flow on profitability of firms by comparing manufacturing sectors in Nigeria and Ghana, from 2012 to 2017.

\section{$1.1 \quad$ Statement of Problem}

Cash flow management is very important for business managers all over the world. It is believed that free cash flow apart from being necessary to take care of unforeseen payment obligations, also contributes to a firm's profitability by making it possible for firms to invest in future profitable business projects. Consequently, firms strive to report huge volume of free cash flow in their quest toward achieving enhanced profitability as well as being seen to be efficient. Financial analysts have favoured firms with higher volumes of free cash flow more than those with lesser volumes. However, there is no consensus as to whether there is a significant positive relationship between free cash flow and firm profitability. Some actually believe that the relationship is negative since funds that would have been deployed to profitable projects are piled up in form of free cash flow. This study investigated the impact of free cash flow and other performance metrics on profitability using a comparative analysis of manufacturing firms operating in Nigeria and Ghana.

\subsection{Research Questions}

This study is focused on providing answers to the following questions:

1. To what extent is the impact of free cash flow on firms' profitability? 
2. What is the relationship between leverage and profitability?

3. What is the relationship between current ratio and profitability?

4. What is the nature of relationship between sales growth and profitability?

\subsection{Objective of the study}

1. To examine the impact of free cash flow on profitability.

2. To examine the impact of leverage on profitability.

3. To examine the impact of current ratio on profitability.

4. To examine the impact of sales growth on profitability.

5. To examine the impact of asset tangibility on profitability.

6. To further examine the impact of firm size on profitability.

\subsection{Hypotheses}

The hypotheses are stated in Null form

$\mathbf{H}_{01}$ : There is no significant relationship between free cash flow and profitability of firms

$\mathbf{H}_{02}$ : There exists no significant relationship between leverage and the profitability of firms

\section{Literature Review}

The review of literature provides an insight into the study's associated literature, conceptual framework, and theoretical framework.

\subsection{Conceptual Review}

This section gives explanations to the relevant concepts associated with the study, their measurements and apriori expectation in terms of their relationship with the dependent variable.

\subsubsection{Return on Assets (ROA):}

5. What is the nature of relationship between a firm's tangible assets and profitability?

6. To what extent does the size of a firm impact on its profitability?

The primary objective of the study is to examine the impact of free cash flow on the profitability of firms in Nigeria and Ghana.

$\mathbf{H}_{03}$ : There exists no significant relationship between current ratio and the profitability of firms

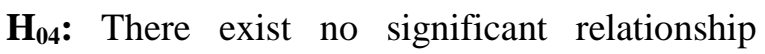
between sales growth and profitability of firms

$\mathbf{H}_{05}$ : There exists no significant relationship between tangibility of assets and profitability of firms

$\mathbf{H}_{06}$ : There exists no significant relationship between firm's size and profitability of firms

\subsection{Scope of study}

This study examined the impact of free cash flow (FCF) on the profitability of quoted manufacturing firms in the Nigerian and Ghana stock exchanges. Data pooled were from twenty (20) different companies (ten each from Nigeria and Ghana) for period of six years from 2012 to 2017.

This is a profitability measurement metric that relates the profit made by the organization to the total assets deployed in making the profits. Many authors adopt this in preference to its closest profitability measurement rival (return on equity) because the result is not affected by the firm's capital structure. The most acceptable form of its computation which we will adopt in this study is profit before interest and taxes divided by total assets.

\subsubsection{Free Cash Flow (FCF)}


Free Cash flow is the excess of net operating cash flow over capital expenditures. It is the cash flow available to the company's suppliers of debt and equity capital after all operating expenses have been paid and necessary investment in working capital and capital expenditures have been made (CFA Curriculum, 2018). It is computed as follows:

$\mathrm{FCF}=\mathrm{NI}+\mathrm{NCC}+\mathrm{INT}$ (1-Tax rate) + CAPEX + WCINV, where,

$\mathrm{NI}=$ Net Income; FCF $=$ Free Cash flow; NCC $=$ Non-Cash charges; INT $(1-$ Tax rate $)=$ Taxadjusted interest expense; CAPEX $=$ Capital Expenditure and WCINV = Working Capital Investment. The relationship between free cash flow and return on assets is not certain and we expect it to be either positive or negative in this study

\subsubsection{Leverage (LEV)}

A company's leverage measures the extent to which the assets of the company are financed by debt capital relative to equity capital. Leverage provides cushion to the company giving it opportunity to fund profitable projects without issuing additional equity capital. The interest paid on loans is usually based on a fixed rate and is tax-deductible. Leverage is believed to be beneficial to firms up to a point considered optimal. Beyond this point, the cost (including bankruptcy cost) may outweigh the benefits. Leverage is computed as total debt capital divided by total assets of the company. We expect either a positive or negative impact on profitability

\subsubsection{Current Ratio (CR)}

This is a liquidity measure that shows the ratio of total current assets to current liabilities. It shows a company's margin of safety (or otherwise) if all the current obligations are to fall due and payable at the same time out of the current assets. It is computed as current assets divided by current liabilities. A ratio of $1 ; 1$ is considered to be the minimum safety threshold for most companies while any ratio above $1: 1$ increases the margin of safety

\subsubsection{Sales Growth (SG)}

Sales growth is a measure of volume and shows a company's growth in terms of the topline which is used to measure market share. This is computed as current sales minus previous sales divided by previous sales. It is expected that a firm with growing sales volume will witness increase in profitability, given the same level of investment. However, the impact might be different if the volume increase is done at a reduced price, leads to heavy bad debts or is preceded by a heavy increase in capital expenditure thus leading to reduced return. The impact of sales growth on profitability may therefore be positive or negative depending on the circumstances

\subsubsection{Asset Tangibility (AT)}

This measures the extent to which a firm deploys tangible assets in its operations. Tangible assets such as plants and machineries are believed to significantly contribute to production and enhanced value for the firm. Apart from its value in production, tangible assets are known to have more external (second hand value) than intangible assets. Asset tangibility is computed as the ratio of tangible assets to the total assets of the company and its impact on profitability is expected to be positive

\subsubsection{Firm Size (FS)}

A firm size measures how big (or small) a firm is in terms of total assets. A big firm is expected to benefit more from scale efficiency which will in turn positively impact on profitability. However, it is also believed that when a big firm is not properly managed, it might lead to operational inefficiency which will negatively impact profitability. Firm size is computed as the log of total asset of a firm and the impact on profitability could be either positive or negative

\subsection{Empirical Review}

[5] conducted a five-year (2012-2016) survey on the impact of free cash flow on the growth rate quoted non-financial companies in Nigeria. The study found that free cash flow has an adverse effect on the growth rate of businesses. It thus established that free cash flow is capable of 
eroding growth prospects of companies quoted on the Nigerian stock exchange [3], examined the relation between the relationship between free cash flow for a firm and its profitability. Data was collected from 28 listed companies in Bangladesh Stock Exchange from 2011 to 2016. Two panel regression models and the dependent variable of return on equity (ROE) and earnings per share (EPS) as proxy variable of profitability and FCF as the independent variable along with some other control variables were used. The result showed a positive relationship between free cash flow and profitability. [18], conducted a study on the impact of free cash flows on the output of the Vietnam-listed manufacturing and real estate companies. The study revealed a positive relationship between cash flows across all industries and company profitability. The link between companies with and without investment opportunities was however different.

Similarly, [28] studied the impact of free cash flow on profitability of listed companies, using the method of stratified sampling to select sample of 30 companies. Dependent variable was profitability while independent variables included cash flows, capital liquidity and company size. The conclusion was that free cash flow is the most significant financial measure

\subsection{Theoretical Framework}

\subsubsection{The Free Cash Flow Theory}

According to [21] the principle of free cash flow suggested that managers tend to act in a way that maximizes income. Alternatively, managers prefer to use the cash flow increment to achieve targets that have little to do with increasing profits and much to do with making the lives of management easier (such as growing their company's size), or more conveniently. The theory holds that acquisition of assets reduces the free cash flow available to pursue the selfish interest of managers. [13], stated that managers with free cash flow tend to waste cash on excessive acquisition of assets that may not maximize shareholders' wealth. Again, managers are more likely to use the free cash flow to make investments that will be amongst others as it predicts well whether a company is financially healthy or not and whether new opportunities will be added in the future. [8] investigated the impact of free cash flows on the profitability of firms listed at the Karachi Stock Exchange (KSE). The population consisted of 580 companies listed in KSE and the study covered a period of five years (2010 2014). The results revealed that free cash flow and size of firm influence firms' profitability while capital liquidity does not. [29] provided evidence that free cash flow leads to a rise in dividend yield and those companies with low growth are having a stronger effect. The study found that a significant positive relationship exists between dividend policies free cash flow for companies with low-growth but the relationship seems negligible for high-growth companies. [32] determined the relation between cash-flow and profitability of Indian companies in which four companies were selected for a sixyear period from April 2008 to March2014. The results from the study indicated a positive correlation between the companies' free cash flow and profitability. The degree of relationship between the variables (free cash flow and profitability) differ however as the company changes.

incremental to the size of the firm than to forfeit dividend to the shareholders or repurchase outstanding shares. One implication of the agency theory is that companies with free cash flows are likely to grow beyond the optimum point of shareholders' wealth maximization. Any management decision stopping such excessive expenditures would favor the shareholders of such companies.

\section{$3 \quad$ Methodology}

This study made use of secondary data drawn from the audited accounts of selected companies. Panel data estimation techniques was used since data were collected from a cross section of ten quoted manufacturing 
firms each from Nigeria and Ghana over a period of six years (2012-2017). Convenience sampling technique was used to select the companies that were used for the study. All the selected companies are quoted on the respective stock exchanges of the two countries.

We adopted Return on Assets (ROA) as an acceptable measure of firm profitability because it measures the return based on the total assets available for business in an organization. It is therefore a total return measure which excludes the effect of leverage. The ROA is the dependent variable while free cash flow and other variables are the explanatory variables. The econometrics multiple regression model was used to ascertain the relationship between free cash flow and the profitability as shown below:

$$
\text { ROA = F (FCF, LEV, CR, SG, AT, FS), }
$$$$
\mathrm{ROA}_{\text {it }}=\beta_{0}+\beta_{1} \mathrm{FCF}_{\text {it }}+\beta_{2} \mathbf{L E V}_{\text {it }}+\beta_{3} \mathrm{CR}_{\text {it }}+
$$
$\beta_{4} \mathrm{SG}_{\mathrm{it}}+\beta_{5} \mathrm{AT}_{\mathrm{it}}+\beta_{6} \mathrm{FS}_{\mathrm{it}}+\mu$

Where;

$\beta_{0}$ is the intercept while $\beta_{1}, \beta_{2}, \beta_{3}, \beta 4, \beta 5, \beta_{6}=$ Regression slope measuring the magnitude of the increase in profitability (ROA) with a change in unit of the independent variable,

ROAit $=$ Return on assets for firm $\mathrm{i}$ at time $\mathrm{t}$ which is estimated as earnings before interest and taxes / total assets

$\mathbf{F C F}_{\mathbf{i t}}=$ Free cash flow firm $i$ at time $t$, estimated as operating cash flow minus capital expenditures

$\mathbf{L E V}$ it $=$ Leverage firm $i$ at time $t$, estimated as total debt/total assets

$\mathbf{C R}_{\mathbf{i t}}=$ Current ratio firm $i$ at time $t$, estimated as current assets/ current liabilities

$\mathbf{S G}_{\mathbf{i t}}=$ Sales growth of firm $i$ at time $t$, estimated as the percentage change in sales value

$\mathbf{A T} \mathbf{T}_{\mathbf{i t}}=$ Asset tangibility of firm $i$ at time $\boldsymbol{t}$, estimated as ratio of tangible assets to total assets
$\mathbf{F S}_{\mathbf{i t}}=$ Firm size firm $i$ at time $t$, estimated as the natural $\log$ of total assets

$\boldsymbol{\mu}=$ Error term

\subsection{Method of data Analysis}

This study made use of panel regression techniques. The regression panel deals with data from the two-dimensional cross sectional (manufacturing firm)/time series (2012-2017). The study used the method of data analysis with fixed effect for Nigeria and the random effect for Ghana.

\section{Presentation and Analysis of Results}

This research examined the impact of free cash flow on profitability of firms by comparing manufacturing sectors in Nigeria and Ghana, from 2012 to 2017.

The analysis included only manufacturing companies that released their audited financial reports annually from the period 2012 and 2017. Data from ten Nigerian and Ghana manufacturing firms each formed the sample for the study. In ensuring acceptable observation for statistical testing, the study adopted panel data. This is to identify the specific indicators of the possible company in selected manufacturing firms quoted in Nigeria and Ghana. To this end, we conducted panel data regression of the fixed effect and random effect and the Hausman test was conducted to distinguish between the fixed effect and random effect models. The study variables include the profitability indicator (ROA) as the dependent variable whereas the independent variables were leverage (LEV), free cash flow (FCF), current ratio (CR), sales growth (SG), tangibility of assets (AT), and firm size (FS)

\subsection{Regression Results}


We used panel data regression to analyze the cause-effect relationship between the dependent variables (ROA) and the independent variables and to check the formulated hypotheses, given that the data are time series (2012 to 2017) and cross-section properties (10 quoted

Table-1. Panel regression Results for Ghana

\begin{tabular}{|c|c|c|c|c|c|c|}
\hline & \multicolumn{3}{|c|}{ FIXED EFFECT MODEL } & \multicolumn{3}{|c|}{ RANDOM EFFECT MODEL } \\
\hline VARIABLE & COEFFIECIENT & T-STAT & $\begin{array}{l}\text { P. } \\
\text { VALUE }\end{array}$ & COEFFIECIENT & T-STAT & $\begin{array}{l}\text { P- } \\
\text { VALUE }\end{array}$ \\
\hline C & 0.005559 & 0.015189 & 0.9880 & -0.261528 & -1.59913 & 0.1159 \\
\hline FCF & $-1.90 \mathrm{E}-08$ & -0.10375 & 0.9198 & $5.29 \mathrm{E}-08$ & 0.301569 & 0.7642 \\
\hline AT & -0.11139 & 0.992677 & 0.3264 & -0.148991 & -1.87209 & 0.0668 \\
\hline SG & $-1.69 \mathrm{E}-05$ & -0.00229 & 0.9982 & 0.005259 & 0.738577 & 0.4635 \\
\hline CR & -0.00115 & -0.10394 & 0.9177 & 0.00067 & 0.065362 & 0.9481 \\
\hline LEV & -0.37204 & -3.40558 & 0.0014 & -0.371418 & -4.53413 & 0 \\
\hline AS & 0.07873 & 0.896072 & 0.3752 & 0.104696 & 2.877503 & 0.0058 \\
\hline $\mathrm{R}^{2}$ & \multicolumn{3}{|l|}{0.752762} & \multicolumn{3}{|l|}{0.426171} \\
\hline & \multicolumn{3}{|l|}{0.660766} & \multicolumn{3}{|l|}{0.348925} \\
\hline Statistics & \multicolumn{3}{|l|}{$8.182576(0.0)$} & \multicolumn{3}{|l|}{$5.517051(0.0)$} \\
\hline & \multirow{2}{*}{\multicolumn{3}{|c|}{$\begin{array}{c}- \\
10(6)\end{array}$}} & \multicolumn{3}{|l|}{$7(0.0981)$} \\
\hline & & & & $10(6)$ & & \\
\hline DW & \multicolumn{3}{|l|}{2.08} & \multicolumn{3}{|l|}{1.64} \\
\hline
\end{tabular}

Table-2. Panel Regression Results for Nigeria

\begin{tabular}{|c|c|c|c|c|c|c|}
\hline & \multicolumn{3}{|c|}{ FIXED EFFECT MODEL } & \multicolumn{3}{|c|}{ RANDOM EFFECT MODEL } \\
\hline VARIABLE & COEFFIECIENT & $\begin{array}{c}T- \\
\text { STAT }\end{array}$ & $\begin{array}{l}\text { P.- } \\
\text { VALUE }\end{array}$ & COEFFIECIENT & $\begin{array}{c}T- \\
\text { STAT }\end{array}$ & $\begin{array}{c}\text { P. } \\
\text { VALUE }\end{array}$ \\
\hline C & 1.1541077 & 1.48319 & 0.1481 & 0.062460 & 0.36279 & 0.7183 \\
\hline FCF & $7.96 \mathrm{E}-11$ & 0.49573 & 0.6236 & $7.06 \mathrm{E}-11$ & 0.37900 & 0.7063 \\
\hline AT & -0.100997 & $\overline{0.66338}$ & 0.5309 & -0.457535 & 5.84367 & 0.0000 \\
\hline SG & 0.020215 & 2.17497 & 0.0374 & 0.011234 & 1.09457 & 0.2788 \\
\hline CR & -0.001353 & 0.62058 & 0.5394 & -0.003533 & 2.19941 & 0.0032 \\
\hline LEV & -0.166002 & $\overline{0.99008}$ & 0.3298 & -0.168002 & $\overline{0.11388}$ & 0.1389 \\
\hline AS & -0.166248 & $i, 02228$ & 0.3146 & 0.045457 & 0.04546 & 0.0376 \\
\hline & \multicolumn{3}{|l|}{0.940215} & \multicolumn{3}{|l|}{0.427520} \\
\hline $\begin{array}{l}\text { Adjusted } \\
\mathbb{R}^{2}\end{array}$ & \multicolumn{3}{|l|}{0.907430} & \multicolumn{3}{|l|}{0.348945} \\
\hline $\begin{array}{l}\text { F- } \\
\text { Statistics }\end{array}$ & \multicolumn{3}{|l|}{$28.67816(0.0)$} & \multicolumn{3}{|l|}{$5.44087(0.0)$} \\
\hline $\begin{array}{l}\text { Hausman } \\
T\end{array}$ & \multirow{2}{*}{\multicolumn{3}{|c|}{$7(0.0000)$}} & \multicolumn{3}{|l|}{-} \\
\hline & \multirow{2}{*}{\multicolumn{3}{|c|}{ 10(7) }} & & & \\
\hline DW & & & & \multicolumn{3}{|l|}{$\begin{array}{l}1.64 \\
1.01\end{array}$} \\
\hline
\end{tabular}

manufacturing firms each from Nigeria and Ghana). The outcome of the panel data regression obtained is the two ROA results for Nigeria and ROA results for Ghana, and the results are presented and discussed below.

\subsection{Analysis of Result}

The estimated fixed effect and random effect models results for Ghana are shown in Table 1 above while that of Nigeria are shown in Table 2. Hausman tests were done for both Nigeria and Ghana in order to choose which model is more suitable between fixed and random effect models. The null hypothesis is that the preferred model is random effect model while the alternative hypothesis is that fixed effect model is preferred. Since the probability value in Ghana's Hausman test is 0.0981 (greater than 0.05 level of significance, we do not have enough evidence to reject the null hypothesis and so random effect model is the preferred model. In Nigeria however, the probability value in the Hausman test is 0.0000 which is less than 0.05 . We therefore reject the null hypothesis and choose the fixed effect model as the appropriate model.

In Table 1, the results of the random effect show that the $\mathrm{R}^{2}$ and adjusted $\mathrm{R}^{-2}$ values were (0.426171) and (0.348925). This indicates that all independent variables jointly explain about 34.89 per cent of the systemic variations in return on assets (ROA) across the 10 cited manufacturing companies in Ghana sampled in this study and over the six-year period (20122017). Similarly, the $R^{2}$ and adjusted $R^{2}$ values in Table-2 were (0.940215) and (0.907430) respectively. This also means that all independent variables describe about 90.7 per cent of the systemic differences in return on assets (ROA) in Nigeria together. The Fstatistics (5.517051) and (28.67816) and their pvalues $(0.0)$ and $(0.0)$ respectively in both tables indicate that the overall test results in both Ghana's ROA panel random regression model and that of Nigeria are significant at $1 \%$. 
Durbin-Watson statistics (DW) is a test of autocorrelation. DW test of auto-correlation usually ranges from 1 to 4 . A rule of thumb is that DW test statistics between 1.5 to 2.5 are relatively normal. The DW results of 1.64 and 1.76 respectively for Ghana and Nigeria confirm the models are free of autocorrelation problems.

\subsection{Discussion of Result}

This study examined the impact of free cash flow on the profitability of the Nigerian and Ghana manufacturing companies. The analysis that follows is based on Tables $1 \& 2$ above and test of significance is based on $95 \%$ confidence level (i.e. p-value less than 0.05)

$\mathbf{H}_{01}$ : The p-values in Tables 1 and 2 and positive coefficients for free cash flow revealed similar results from the relationship between the indicators in Nigeria and in Ghana. The results show that free cash flow has a positive but insignificant relationship with profitability of manufacturing firms in Ghana as well as in Nigeria. These findings imply that free cash flow enhances the ability of the firm to invest on assets with a positive net present value and thus impact positively on the bottom line of the business though negligible. This result was consistent with [27] which established a positive but negligible relationship between free cash flow and corporate results.

$\mathbf{H}_{\text {02: }}$ The study further revealed that leverage has a negative and significant relationship with profitability of manufacturing firms in Ghana but that of Nigeria is insignificant. This conforms to the expectation that high debt in a financing structure can lead to a decrease in riskadjusted returns. This conforms to the findings of [4] that confirmed an inverse relationship between financial leverage and profitability of firms operating in the cement section in Pakistan. Also [17], found that leverage has a negative relationship with the firms' value and increases business and financial risk of the firm. However, they concluded that despite the negative impact of high leverage, it also increases the returns for shareholders if the optimal level can be achieved.
$\mathbf{H}_{03}$ : The study found that current ratio has a positive and insignificant relationship with profitability of manufacturing firms in Ghana while a negative relationship is established for firms' in Nigeria. This is at variance with the findings of [14] that established no relationship between liquidity variables and profitability of firms in the Foods sector in Bursa. The result in Ghana conforms to the findings of [15] but contradicts that of [2] which established a weak positive relationship between liquidity and profitability in Chartered Bank of Pakistan

$\mathbf{H}_{04}$ : The study also found that sales growth has a positive and insignificant relationship with profitability of manufacturing firms in Ghana while that of Nigeria is both positive and significant. This means that sales growth has a positive relationship with profitability in the manufacturing sector of both countries, since sales revenue drives profit when costs are minimized. However, when sales growth is achieved with decreased profit margin, the impact on profitability may be negligible. The positive effect of sales (volume) growth was also established in the studies by Isik, [19].

$\mathbf{H}_{05}$ : The results showed that the tangibility of assets in Nigeria and Ghana has a negative and insignificant relationship to the profitability of manufacturing companies. This could result from firms not doing adequate analysis before embarking on fixed assets investments and thus depress profitability when the associated depreciation is charged to the profit generated by the assets. [9], concluded that a high ratio will enable firm to liquidate more asset during bankruptcy.

Ho6: While firm sizes showed a positive and significant relationship with the profitability of firms in Ghana, it showed a negative yet negligible relationship with Nigerian corporations. The findings in Ghana are in conformity with that of [7] which established a positive relationship between firm size measured by total assets and firm profitability. The implications of the results in both countries are that size could affect a company in either positive or negative way due to economies of scale or inefficiency. 


\subsection{Conclusion}

The outcome of this study showed similar results for the two countries in four out of the six variables and mixed results for two variables. For both countries, positive relationship was established between profitability as dependent variable and free cash flow and sales growth as independent variables while negative relationship was established with asset tangibility and leverage. In Ghana, profitability had a positive relationship with credit ratio and firm size while a negative relationship was established in the case of Nigeria for both variables. The implication of the outcome of the study in both countries is that there is no sufficient evidence to show that free cash flow increases a firm's profitability. Also, the lack of statistical significance between profitability and current ratio (another measure of liquidity) in the countries points to the same direction. In fact, in the case of Nigeria, the negative relationship between profitability and current ratio points to the danger of over investment in working capital as this can ultimately depress profitability. Also, the study points to the importance of sales growth in improving a firm's profitability. With constant erosion of profit margin in a highly competitive world, the importance of volume growth cannot be over emphasized. Finally, the significant negative relationship between profitability and leverage highlights the risk in heavy borrowing especially in high interest rate environment

\subsection{Recommendations}

In the light of the above findings, we therefore recommend the following;

1. Corporate managers should always maintain an optimum level of free cash flow that is required to take care of any unforeseen events. They should however avoid piling up idle funds in the hope that it will eventually lead to higher profitability
2. Firms should be careful on how they enter into debt financing especially in countries where the cost of debt is very high. Any low-income project financed with high priced debt sources will obviously result to negative returns.

3. Investment in working capital should be at the optimum level. Excess working capital investment should be avoided

4. Firms should strive to achieve sales growth. However, this should be done be done without weakening the profit margins

5. Firms should always carry out thorough analysis prior to investing in fixed assets so as to invest only in assets that generate positive net present value which will increase the profitability and the value of the firm

\section{Author's Contribution}

1. EMEKA BENNETT NWUBA; CONCEPTUALIZATION, WRITING-ORIGINAL DRAFT \& METHODOLOY

2. ALEXANDER EHIMARE OMANKHANLEN; SUPERVISION

3. PEACE ONYEDIKACHI CHIMEZIE; REVIEW \& EDITING

4. LAWRENCE UCHENNA OKOYE; PROJECT ADMINISTRATION

\section{Acknowledgements:}

We want to acknowledge Covenant University Centre for Research, Innovation and Development (CUCRID) for providing an enabling environment for this research.

\section{References:}


[1] Adelegan, O. (2003). An empirical analysis of the relationship between cash flow and divided charges in Nigeria. Journal of Research in Development and Management 15. 35-49.

[2] Ahmad, R. (2016). A study of relationship between liquidity and profitability of Standard Chartered Bank, Pakistan: Analysis of financial statement approach. Global Journal of Business and Management Research. C Finance, 16(1), 77-82.

[3] Ahmed, U.W., Hasan M., Hoque A. \& Alam, M.J. (2018). Impact of Free Cash Flow on Profitability: An Empirical Study on Pharmaceutical Company. Journal of Jessore University of Science and Technology 3(0), 2521-5493.

[4] Ahmed, N., Salman, A. Shamsi, A.F. (2015). Impact of financial leverage on firm profitability: an investigation from cement section of Pakistan. Research Journal of Finance and Accounting, 6(7), 75-80.

[5] Akinleye, G.,Odunayo M. \& Fajuyagbe, K. (2018). Free cash flow and firms' growth: An Empirical Investigation of Nigerian Quoted Non-Financial Firms. Journal of Economics and Behavioral Studies. 10(3), 258-267.

[6] Akumu, O. (2014). Effect of free cash flow on profitability of firms listed on the Nairobi securities exchange

[7] Akinyomi, O.J. \& Olagunju, A. (2013). Effect of size on profitability: evidence from Nigerian manufacturing sector. Prime Journal of Business Administration and Management, 3(9), 1171-1175

[8] Ambreen, S., \& Aftab, J. (2016). Impact of free cash flow on profitability of firms listed in Karachi Stock Exchange. Euro-Asian Journal of Economics and Finance, 4(4), 113-122

[9] Baker, H.\& Gerald S. (2011). Capital structure and corporate financing decision: Theory, Evidence and Practice. USA: John Wiley \& Sons Ltd
[10] Bhutta, N., \& Hasan, A. (2013). Impact of firm specific factors on profitability of firms in food sector. Open Journal of Accounting, 2(4), $19-25$.

[11] CFA Program Curriculum (2018), Level 1, Volume 3, Financial Reporting \& Analysis

[12] Cheng, Z., Cullinan, C. \& Zhang, J. (2014). Free cash flow, growth opportunities, and dividends: Does Cross-Listing Of Shares Matter? Journal of Applied Business Research, 30(2), 587.

[13] Donaldson, G. (1997). Managing Corporate Wealth. New York: Praeger.

[14] Durrah, O., Rahman, A.A., Jamil, S.A. \& Ghafeer, N.A. (2016). Exploring the relationship between liquidity ratios and indicators of financial performance: an analytical study of food industrial companies listed in Amman Bursa. International Journal of Economics and Financial Issues, 6(2), 435-441.

[15] Eljelly, A. (2004). Liquidity-profitability tradeoff: an empirical investigation in an emerging market. International Journal of Commerce and Management, 14(2), 48-61. https://doi.org/10.1108/10569210480000179

[16] Habib, A. (2011). Growth opportunities, earnings permanence and the valuation of free cash flow. Australasian Accounting, Business and Finance Journal, 5(4), 101-122.

[17] Hanafi, M.\&Halim, A. (2007). Financial statement analysis [AnalisaLaporanKeuangan]. Yogyakarta: UPP YKPN.

[18] Hau, L (2017). Free cash flow and firm performance: Evidence from Sectoral levels for Vietnamese Listed Firms. International Journal of Advanced Engineering, Management and Science, 3(4), 296-300.

[19] Isik, O., Unal, E.A. \& Una, Y. (2017). The effect of firm size on profitability: evidence from Turkish manufacturing sector. Journal of Business, Economics and Finance, 6(4), 301308 
[20] Jafari, S., Gord, A., \& Beerhouse, M. (2014). The effect of debt, firm size and liquidity on investment cash flow sensitivity of listed companies in Tehran stock exchange. Arabian Journal of Business and Management Review (Nigerian Chapter) 2 (10)

[21] Jensen, M. (1996). The takeover controversy: Analysis and Evidence. (J. C. Ackerman, Ed.) Midland Corporate Finance Journal.

[22] Jensen, M., Clifford, H., \& Smith, C. (1995). Stockholder, manager and creditor interests: Applications of Agency Theory. Recent Advances in Corporate Finance. Homewood, Illinois: Irwin.

[23] Kamran, M., Zhao, Z., \&Ambreen, S. (2017). Free cash flow impact on firm' $s$ profitability: An Empirical Indication of Firms listed in KSE , Pakistan. European Online Journal of Natural and Social Sciences, 6(1), 146-157

[24] Lang, L., Stulz, R. \&Walkling, R. (1991). A test of the free cash flow hypothesis: The case of bidder returns. Journal of Financial Economics, 29(2), 315-335.

[25] Nasimi, A. (2016). Effect of capital structure on firm profitability (An Empirical Evidence from London, UK). Global Journal of
Management and Business Research, 16(4), 820.

[26] Nor Hasmadila, M. (2014). Corporate governance and cash flow as determinants of dividend payout. Universiti Utara Malaysia.

[27] Opondo, M. (2004). Using earnings and free cash flow to evaluate corporate performance, Unpublished MBA Project, University of Nairobi

[28] Sadaf Ambreen, J. (2016). Impact of free cash flow on profitability of the firms listed in karachi stock exchange. Euro-Asian Journal of Economics and Finance, 4(4).

[29] Sáez, M. \& Gutiérrez, M. (2015). Dividend policy with controlling shareholders. Theoretical Inquiries in Law, 16 (1), 107-130.

[30] Serrasqueiro, Z. \&Nunes, P.(2008). Performance and Size: Empirical Evidence from Portuguese SMEs. Small Business Economics, 31 (2), 195-217.

[31] Sheng- Syan\& Chou, Shu- Fen Chou,( 2009). The impact of investment opportunities and free cash flow on financial liberalization. Journal of Management.

[32] Thangjam R, (2015). Analysis of relationship between profitability and free cash flow to firms. International Journal in management and social science, 03(08)

\section{Creative Commons Attribution License 4.0 (Attribution 4.0 International, CC BY 4.0)}

This article is published under the terms of the Creative Commons Attribution License 4.0

https://creativecommons.org/licenses/by/4.0/deed.en US 